\title{
A MOLECULAR DIAGNOSTIC FOR WILT DISEASES OF BANANA IN SOUTH KALIMANTAN, INDONESIA
}

\author{
Dewi Fitriyanti and Lyswiana Aphrodyanti* \\ *Department of Plant Pest and Disease, Faculty of Agriculture, \\ Lambung Mangkurat University, Banjarbaru, South Kalimantan \\ Jl. A. Yani Km 36 Kotak Surat 1028, Banjarbaru (70714) South Kalimantan,
}

\begin{abstract}
Among other provinces in Indonesia, South Kalimantan used to be known as one of the most famous local suppliers of bananas, especially for Java and Bali. However, since 2006 the productivity has declined dramatically due to the disruption of plant diseases. The early, fast, accurate and precise detection of the disease is needed in order to control the disease appropriately. One of the most useful, fast and accurate diagnostics that was carried out in this research was Polymerase Chain Reaction (PCR). This molecular technique has never been carried out before to detect banana diseases in South Kalimantan. This research aimed to identify the sick banana plants taken from 13 locations in 6 (six) regencies in South Kalimantan Indonesia, representing banana planting areas: Banjarbaru City, Batola, Tanah Laut, Tapin, Hulu Sungai Selatan and Hulu Sungai Tengah regencies. The results showed that the disease of all banana plant samples was positively identified as Blood Diseased Bacteria (BDB). It was established by the electroforesis result after being viewed under UV illumination that the band was at the same position as the positive control (BDB), $317 \mathrm{bp} .7 \mathrm{bp}$.
\end{abstract}

Keywords: Banana, molecular diagnostic, wilt diseases

\section{INTRODUCTION}

In South Kalimantan, banana plants have been planted from generation to generation. Not less than three regencies of banana suppliers have been contributing to the local income after the coal mining and paddy field. However, of course, in developing this plant there are always some constraints faced by the farmers in the cultivation, such as the attack of plant diseases.

There were two diseases that had been reported attacking banana plants in South Kalimantan, i.e wilt diseases caused by Fusarium oxysporum f. sp. cubense and Ralstonia solanacearum. In 2003, it was reported that these diseases attacked 1,246 ha of banana fields and in 20041,750 ha, and in 2005 the infection rates increased to 7,455 ha (BPTPH South Kalimantan, 2005).

There are many diseases that can attack banana plants in Indonesia. Banana Blood Disease caused by a bacterium called the Blood Disease Bacterium (BDB) (EdenGreen and Sastraatmadja, 1990) is the disease resulting in greater losses than any other diseases on banana plants (Sequeira., 1998). These bacteria can spread quickly to the healthy plants and result in a severe damage to banana fields in a short time and therefore result in low productivity to the farmers. This condition is aggravated by the continuous planting of the same banana variety, Kepok. Kepok variety is known to be the most susceptible to BDB (Subandiyah, 2005). This was also the reason why the target used to detect in this research was BDB primers. It aimed to prove that the BDB was the cause of the severe loss of bananas in most banana planting areas in South Kalimantan, Indonesia.

The long lab procedure to detect the cause of the disease can also be one of the constraints to control the disease itself. In addition to the use of conventional lab procedures (physiology, biochemistry, hypersensitivity and pathogenicity test), the fast and highly accurate identification of the disease is also needed to ensure early diagnosis of not only banana diseases but also other diseases. The most common molecular diagnostic technique used to detect plant diseases is Polymerase Chain Reaction (PCR) technique.

In South Kalimantan, this technique is still relatively new to the reseachers, moreover to the farmers. This was also the reason why this research was carried out. By 
using the PCR technique we can confirm the cause of the sick banana and we can also manage the disease control appropriately. It is hoped that by this early, fast and highlyaccurate diagnostic (PCR), the effort to control the banana plant diseases can be done approriately. The early, fast and accurate diagnostic is really necessary so that the preventive disease control measures can be achieved optimally in order to prevent the spread of the disease in the future and therefore the optimal production of banana can also be achieved by the farmers.

\section{MATERIALS AND METHODS}

The research was conducted at the Biological Control Laboratory of Plant Pest and Disease Department, Faculty of Agriculture, Lambung Mangkurat University in Banjarbaru and at the Bacteriology Laboratory and Clinical Laboratory of Plant Protection Department of Gadjah Mada University, Yogyakarta.

The sample of this research was limited to diseased banana plants showing symptoms of Blood Disease Bacteria (BDB) and Wilt Fusarium infections. Blood disease in banana was indicated by a symptom of banana trees with hanging leaf sheath caused by broken leaf sheath that was flaccid. The leaves turned yellow and would eventually have necrosis and become dry. Usually the peel of the fruit looked normal, or sometimes turned yellow earlier, or prematurely ripening and darkening. When the fruit was cut, the center part looked brownish red or was rotting and slimy (Eden-Green and Sastraatmadja, 1990). The transmission of BDB from insects caused the male flower buds turned dark and wilt and the tip of the buds often produced bacterial mass (Subandiyah et al., 2005). Meanwhile, in the case of Fusarium wilt contaminated through the soil, the disease entered through the roots and was spread to the banana leaves. Inside the leaves, the fungi damaged the plant's vessels, causing the plants to wilt and die. The symptoms of the disease were the yellowing of banana leaves (starting from the old leaves and from the sides of the leaves), the breakage of the stem, the discoloration of the vessels, the shortening of the leaf segments, and the discoloration of the infected stem causing stinky smell.

The samples were taken at Tambang Ulang (Tanah Laut Regency), Bangkal Village (Cempaka Sub-district), Barito Kuala Regency, Tapin Regency, Hulu Sungai
Selatan Regency (Kandangan), and Hulu Sungai Tengah Regency (Barabai).

DNA Extraction from Bacterial Suspension

Bacterial suspension was obtained from banana fruits showing BDB symptoms, by taking the necrotic xylem tissue below the epidermis layer and cutting it into small pieces $\left(0.2 \times 0.5 \times 1.5 \mathrm{~cm}^{3}\right)$ and putting it into a tube containing $10 \mathrm{ml}$ of sterile water and stirring it until it became homogeneous. In order to obtain the DNA of the bacteria culture, $100 \mu \mathrm{l}$ suspension was taken and was put on the petri dish dripped with CPG media and was mixed using l-glass. After the colony grew for \pm 4 days, the isolate was harvested and put in the eppendorf tube while the one in the bacterial suspension was moved directly from the suspension to the eppendorf tube. Both the one from the suspension and that from the culture were centrifuged at a speed of 5,000 rpm for 5 minutes in order to obtain the pellet. The pellet was added with $500 \mu \mathrm{l}$ of Tris- $\mathrm{HCl}$ $100 \mathrm{mM}+$ EDTA $50 \mathrm{mM}$ and was centrifuged again at a speed of $5,000 \mathrm{rpm}$ for 5 minutes.

The pellet was then added with $200 \mu \mathrm{l}$ CTAB buffer and was incubated for 15 minutes at a temperature of $65^{\circ} \mathrm{C}$. Next, $500 \mu \mathrm{I}$ CIAA was added and the pellet was rapidly rotated for 1 minute and was centrifuged at a speed of $12,000 \mathrm{rpm}$ for 10 minutes. The resulting supernatant (the upper liquid layer) was taken so carefully that it was not mixed with the pellet and was moved to another eppendorf tube. Then, $1 \mathrm{ml}$ ethanol of $96 \%$ absolute was added to the supernatant and was incubated at a temperature of $-20^{\circ} \mathrm{C}$ overnight. Next, the supernatant was centrifuged again at a speed of $12,000 \mathrm{rpm}$ for 10 minutes and the supernatant was disposed. The resulting pellet was added with $1 \mathrm{ml}$ cold alcohol $70 \%$ and was stirred and centrifuged again at a speed of $12,000 \mathrm{rpm}$ for 10 minutes. Again, the resulting supernatant was disposed and the resulted pellet was let dry on laminar air flow for \pm 1 hour. The dry pellet was re-suspended by adding buffer TE $20 \mu \mathrm{l}$ and was kept at a temperature of $-20^{\circ} \mathrm{C}$.

Total DNA Extraction from Diseased Plant Material (Necrotic Banana Leaf)

The DNA extraction from the necrotic banana leaf was obtain by, first, sanitizing the surface of the leaf using alcohol $70 \%$, then cutting the leaf into a size of $\pm 1 \mathrm{~cm}^{2}$ and a weight of 10 gram per each, and putting each of them into a porcelain mortar. Then, liquid nitrogen was added and the mixture was ground into fine powder. The powder was put into a $1.5 \mathrm{ml}$ micro-centrifuge tube and the 
extraction buffer was added until the volume reached $1.5 \mathrm{ml}$. Next, the sample was incubated in a water-bath at a temperature of $60^{\circ} \mathrm{C}$ for 30 minutes. Every 10 minutes it was stirred by hand. After that, the sample was centrifuged at a speed of 5,000 rpm for 5 minutes, the supernatant was moved into a different micro-centrifuge tube, was added with CIAA to reach $1.5 \mathrm{ml}$, and was stirred until homogeneous. After it was centrifuged at a speed of $12,000 \mathrm{rpm}$ for 10 minutes, the supernatant was moved into another micro tube, added with cold ethanol $95 \%$ until reaching $1.5 \mathrm{ml}$, and stirred until homogeneous. Next, the sample was incubated overnight at a temperature of -20 ${ }^{\circ} \mathrm{C}$. Again on the next day, the sample was centrifuged at a speed of $12,000 \mathrm{rpm}$ for 10 minutes and the supernatant was disposed while the pellet was mixed with cold ethanol $70 \%$ until reaching $1.5 \mathrm{ml}$, then the mixture was rotated. The sample was centrifuged again at a speed of $12,000 \mathrm{rpm}$ for 10 minutes and the resulted pellet was let dry on laminar air flow. Afterwards, the pellet was resuspended by adding $50 \mu \mathrm{l}$ sterile aquabides (TE buffer) and was kept at a temperature of $20^{\circ} \mathrm{C}$.

\section{DNA Sample Preparation for BDB Detection using PCR}

The amplification of DNA was conducted using specific primers of $121 \mathrm{~F}, 121$ $\mathrm{R}$, and MMR (Master Mix Royal), $10 \mu$ DNA ladder, and $100 \mathrm{bp}$. There was as much as 1 $\mu \mathrm{l}$ of each sample's DNA that was prepared. The Primers $(121 \mathrm{R}$ and $121 \mathrm{~F}$ were first diluted 10 times) were prepared $1 \mu \mathrm{l}$. After that, the stocks were mixed together $(161 \mu \mathrm{l}$ aquadest $+230 \mu \mathrm{l} M M R+23 \mu \mathrm{l} 121 \mathrm{R}+23 \mu \mathrm{l}$ $121 \mathrm{~F})$ into a tube. Then, $19 \mu \mathrm{l}$ was taken and was put into each sample (19 pieces), then 1 $\mu \mathrm{I}$ DNA of each sample was added. The same treatment was also performed for positive control. There was as much as $1 \mu \mathrm{l}$ of Positive Control that was prepared and $19 \mu \mathrm{l}$ of stock was added into the PCR tubes. Then, the tubes were ready to be put into the PCR machine. The thermal cycling program for PCR was conducted based on the recommendation from Fegan (2005) consisting of initial denaturation cycle at a temperature of $95^{\circ} \mathrm{C}$ for 5 minutes in 1 cycle, then 30 cycles consisting of denaturation process at a temperature of $95{ }^{\circ} \mathrm{C}$ for 30 seconds, primer annealing process to DNA mold at a temperature of $58{ }^{\circ} \mathrm{C}$ for 30 seconds, DNA extension process at a temperature of $72{ }^{\circ} \mathrm{C}$ for 1 minute, then the extension process was ended at $72{ }^{\circ} \mathrm{C}$ for 10 minutes, and finally the program was ended at a temperature of $20^{\circ} \mathrm{C}$.

\section{DNA Sample Preparation for Foc Detection using PCR}

Foc was detected using only culture showing a colony morphology, such as Foc. The mixture of stock consisted of $35 \mu \mathrm{l}$ aquabidest $+20 \mu \mathrm{l} \mathrm{TR} 4 \mathrm{R}+20 \mu \mathrm{l} \mathrm{TR} 4 \mathrm{~F}+50$ $\mu \mathrm{l} \mathrm{MMR}$. After the producing of stock, $19 \mu \mathrm{l}$ stock $+1 \mu$ l DNA were put into each PCR tube.

The samples were ready for detection based on the following PCR program: The program used was FocTR4 with the sample volume $=20 \mu \mathrm{l}$ as the following; $95^{\circ} \mathrm{C}$ for 5 minutes in 1 cycle; $95{ }^{\circ} \mathrm{C}$ for 1 minute in 1 cycle; $60{ }^{\circ} \mathrm{C}$ for 1 minute in $1 \mathrm{cycle}$, and 30 cycles of $72{ }^{\circ} \mathrm{C}$ for 3 minutes; $72{ }^{\circ} \mathrm{C}$ for 10 minutes in 1 cycle ended with $4{ }^{\circ} \mathrm{C}$.

\section{Electrophoresis}

The process of PCR was followed by electrophoresis. It was started by making Gel Agarose $0.8 \%$. The agarose solution, then, was heated in the microwave for \pm 3 minutes. After it was cold, the solution was poured into the electrophoresis tray of $50-\mathrm{ml}$ size with the comb size of 17 wells. The solution was set aside for \pm 45 minutes until it became solid gel. Then, the comb was lifted slowly, and into the well made by the comb, 8 micro of each DNA sample and 5 micro of positive control and marker (100 bp for \pm 300 target) were poured. Next, it was electrophoresed with 90 Volt for 40 minutes by connecting the switches to the source of electric current. When it was finished, the agarose gel was lifted and was soaked in the ethidium bromide solution for \pm 15 minutes. Then, the gel was put on a UV transilluminator device to see the DNA bands formed during electrophoresis process.

\section{RESULTS AND DISCUSSION}

Based on the result of the visualization under the UV transilluminator, it was detected that all diseased banana plant samples taken from 13 locations in 7 regencies and cities in South Kalimantan were positively infected by Blood Disease Bacteria (BDB) (Figure 1).

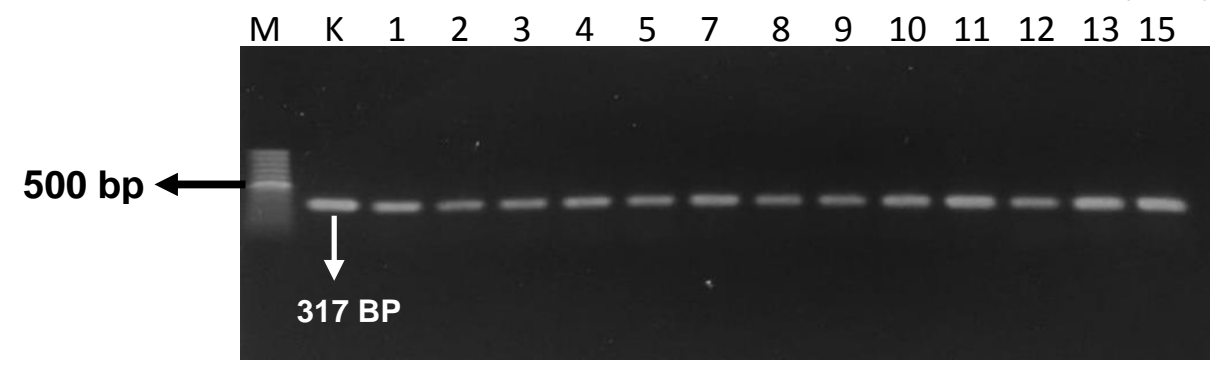


Figure 1. Result of the electrophoresis (visualization under UV transilluminator) DNA of grounded necrotic banana leaves.

Note: (M) Marker (100 bp); (K) Positive Control (317 bp); (1) Tambang Ulang, Tanah Laut (Cavendish banana); (2) Tambang Ulang, Tanah Laut (Kepok banana); (3) Bangkal Village, Cempaka; (5) Barabai District, Hulu Sungai Tengah; (7) Labung Village, Tapin Tengah Sub-district, Tapin District; (8) Harapan Masa Village, Tapin Selatan; (9) Pandulangan Village, Hulu Sungai Selatan; (10) Baru Village, Hulu Sungai Selatan; (11) Parincahan Village, Hulu Sungai Selatan; (12) Sungai Sala Village, Hulu Sungai Tengah; (13) Guntung Manggis Sub-district, Banjarbaru City; (15) Dahirang Village, Barito Kuala.

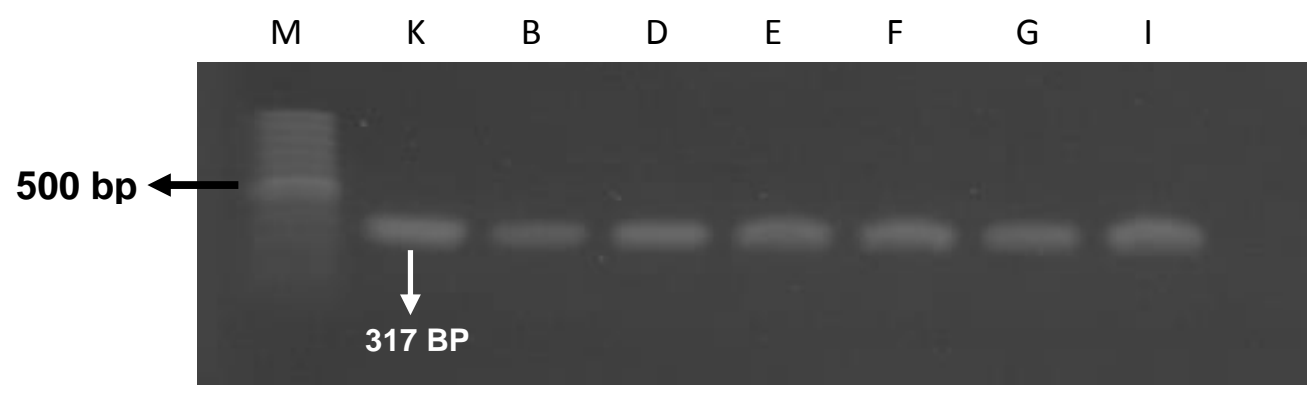

Figure 2. Result of the electrophoresis after the visualization under UV light of the bacterial culture growing at CPG media.

Note: (M) Marker (100 bp); (K) Positive Control (317 bp); (B) Tambang Ulang, Tanah Laut (Cavendish banana); (D) Pandulangan Village, Hulu Sungai Selatan; (E) Parincahan Village, Hulu Sungai Selatan; (F) Barabai District, Hulu Sungai Tengah; (I) Bangkal Village, Cempaka Banjarbaru City.

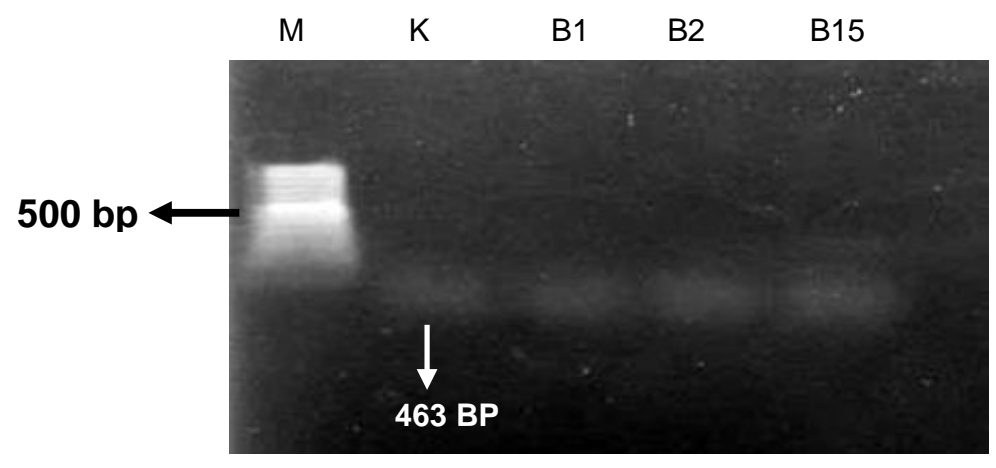

Figure 3. Result of the visualization of Foc culture. Note: $\mathrm{M}=$ Marker (100 bp), $\mathrm{K}=$ Positive Control Note : Foc (463 bp); (B1) Culture No. 1 (Tambang Ulang, Tanah Laut (Kepok Banana); (B2) Culture No. 2 (Tambang Ulang, Tanah Laut (Cavendish banana); (B15) Culture No. 15 (Dahirang Village, Barito Kuala District).

Regarding the detection of diseases in banana plant, in this case BDB and Fusarium diseases, we found out that it very difficult to isolate the BDB and the Fusarium from the sick banana tissue, even by using specific media, especially CPG to isolate the BDB from the fruit part (the tissue under the peel) which was known for its lower saprophytic population compared to the other part's tissue. According to Hadiwiyono (2011), BDB detection using culturable method was very difficult to perform. This was evident from the sample to be identified by us. The sample was indeed very difficult to isolate directly from the sick tissue, but it was very quickly identifiable through molecular technique by using PCR with primers of $121 \mathrm{~F}$ and $121 \mathrm{R}$, which were specific for marking the BDB and 
could not be used as another isolate markers or for other samples. Likewise, the wilt Fusarium oxisporum f.sp cubense also had its own specific primers, i.e. TR4 R and TR4 F. Therefore, the result of the detection performed to the sick banana samples taken from some districts in South Kalimantan showed that even though the sick banana tissue cannot be directly isolated from the specific culture, the use of the molecular detection of PCR technique had helped us to find out that the sick bananas were positive for $\mathrm{BDB}$. This was confirmed by the result of the visualization under the UV in which the samples of the sick bananas had the same DNA bands as that of BDB's DNA, or confirmed by the sample DNA's bands that were parallel with the positive control DNA's bands with the of was $317 \mathrm{bp}$ (Figure 1 and 2).

Meanwhile, the wilt Fusarium might not be found because the samples did not contain wilt Fusarium or because the sick banana plants growing in the locations were dominated by BDB population. Furthermore, most of the bananas planted by the farmers were Kepok banana which was susceptible to BDB (Subandiyah, 2005).

Through a discussion with the local farmers at Sambung Makmur Banjar county, a problem encountered at the banana plantation in this area was that the Kepok variety was no longer able to produce well like it was several years ago as a result of the wilt disease. In our opinion, this is also because there is no concrete effort made to break the disease cycle itself; in other words, a causal agent or the pathogen that has always been in the field due to the food for it is always available in great numbers in the field. Moreover, Kepok variety is known to be highly susceptible to the banana blood disease. The solution to replace or rotate crop varieties with non-host plants is also felt hard to be done by the farmers. The actually mixing planting of banana plant varieties that are susceptible and mild resistance to wilt diseases in one area (Kepok, Talas and Muli) can be the alternative that can be carried out to reduce the vulnerability to banana wilt.

\section{CONCLUSION}

The results showed that the disease of all diseased banana samples taken from some areas in South Kalimantan (Banjarbaru City, Cempaka Sub-district, Batola Regency, Tanah Laut Regency, Tapin Regency, Hulu
Sungai Selatan Regency, Hulu Sungai Tengah Regency) were all positively identified as Blood Disease Bacteria (BDB).

\section{ACKNOWLEGDEMENTS}

This research was funded by PEKERTI Grant and supported by the Biological Control Laboratory of Plant Pest and Disease Department, Faculty of Agriculture, Gadjah Mada University. The authors would also like to show our gratitude to Prof. Siti Subandiyah and Dr. Arif Budiman (our colleagues from Gadjah Mada University) who provided insight and expertise that greatly assisted the research and also for sharing their pearls of wisdom with us during the course of this research.

\section{REFERENCES}

BPTPH Propinsi Kalimantan Selatan (2008). Yearly Report. Balai Penelitian Tanaman Pangan dan Hortikultura (BPTPH) - South Kalimantan Province, Banjarbaru.

Eden-Green, S.J. (1994). Banana Blood Disease, Musa Disease Fact No. 3. International Network for the Improvement of Banana and Plantain, Montpellier. http://www.ipgri.cgiar.org/publicatio ns/pdf/127.pdf. Accessed on 31 January 2013.

Eden-Green, S.J. and Sastraatmadja, H. (1990). Blood Disease in Indonesia. FAO Plant Protection 38: 49-50.

Fegan, M. (2005). Bacterial Wilt Disease of Banana: Evolution and Ecology. In: C. Allen, P. Prior and A.C. Hayward. Bacterial Wilt Disease and the Ralstonia Solanacearum Species Complex. APS Press, Minessota.

Hadiwiyono (2011). Blood bacterial Wilt Disease of Banana: The Distribution of Pathogen in Infected Plant, Symptoms, and Potentiality of Diseased Tissues as Source of Infective Inoculums. Nusantara Bioscience 3: 112-117.

Semangun, H. (1989). Diseases of Horticultural Crops in Indonesia. Gadjah Mada University Press. Yogyakarta.

Sequeira, L. (1998). Bacterial wilt: the missing element in International Banana Improvement Programs. In: 
P.H. Prior, C. Allen, and J.E. Elphinstone. Bacterial Wilt Disease, Molecular and Ecological Aspects. Gosier 22-27 June 1997. INRA. Berlin.

Subandiyah, S., S. Indarti, T. Harjaka, S. N. H. Utami, C. Sumardiyono and Mulyadi (2005). Bacterial Wilt Disease Complex of Banana in Indonesia. In: C. Allen, P. Prior and A.C. Hayward. Bacterial Wilt Disease and the Ralstonia solanacearum Species Complex. APS Press, Minessota.

Supriadi (1999). Cultural and Pathogenicity Characteristics of Isolates Pseudomonas celebensis, The Cause of Blood Disease of Banana. Jurnal hortikultura 9: 126-136. 